\title{
Frail - skrøpelig, sårbar eller skjør?
}

\author{
Adjektivet frail og det tilhørende substantivet frailty har fått økende utbredelse i internasjonal geriatrisk \\ litteratur, men det er uenighet om definisjonen og usikkerhet om hvordan begrepet best bør oversettes.
}

En person som er frail, har redusert motstandskraft mot ytre påvirkninger, svekkede fysiologiske reserver, redusert evne til å opprettholde fysiologisk homeostase og økt risiko for komplikasjoner til sykdom og for bivirkninger av medisinsk behandling (1). Mange vil også si at en person som er frail, har en biologisk alder som er høyere enn den kronologiske, og en forventet gjenstående levetid som er kortere enn gjennomsnittet for sine jevnaldrende. Frailty er dermed et hovedkjennetegn ved en geriatrisk pasient.

Det er internasjonal enighet om at frailty ikke er det samme som sykdom, men der stopper også enigheten. Den amerikanske epidemiologen Linda Fried definerte i 2001 frailty som tilstedeværelsen av minst tre av de fem kjennetegnene utilsiktet vekttap, utmattelse, redusert ganghastighet, lavt fysisk aktivitetsnivå og redusert gripestyrke, og viste at denne definisjonen predikerte sju års overlevelse, uavhengig av klassiske prognostiske faktorer som f.eks. tilstedeværelsen av alvorlig sykdom (2).

Andre har foreslått en definisjon som ligger tettere opp til en klinisk geriatrisk vurdering, og sier at frailty omfatter forhold som redusert selvstendighet i aktiviteter i dagliglivet, kognitive vansker, underernæring, depressive symptomer og polyfarmasi. I en studie av pasienter med kolorektalkreft fant vi at en slik definisjon predikerer postoperative komplikasjoner bedre enn Linda Frieds opprinnelige definisjon fra 2001 (3).

Men hva skal frail hete på norsk? Den vanligste oversettelsen er nok skrøpelig, og kanskje er dette begrepet i ferd med å feste seg. Jeg føler imidlertid at dette ordet har en noe sterkere negativ valør enn det engelske. Hvis man har gått ned i vekt, er fysisk inaktiv og har svakt håndtrykk er man frail etter Frieds definisjon, men ville vi på norsk synes det var rimelig å kalle en slik person for skrøpelig? Jeg har forsøkt å lansere alternativet sårbar (4), men registrerer at det nok er mindre brukt. Et motargument er også at sårbar har en annen engelsk over-

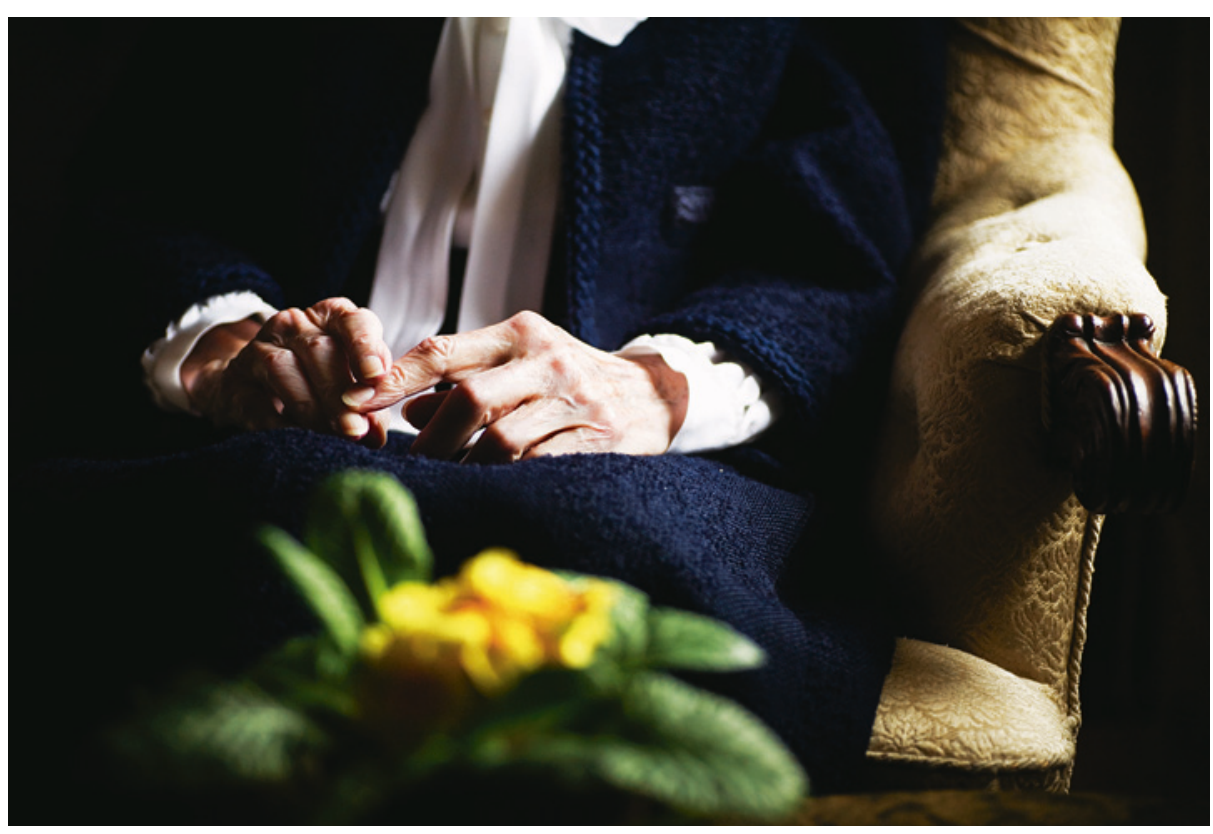

Illustrasjonsfoto: Adam Haglund/NTB Scanpix

settelse, nemlig vulnerable, som ikke er akkurat det samme som frail. Et tredje alternativ kunne være $s k j ø r$, for en skjør gjenstand går som kjent lett i stykker. Problemet er at dette ordet $\mathrm{i}$ folkelig dagligtale like gjerne kan bety sprø eller skrullete, og det er noe annet!

Mitt forslag er at skrøpelig og sårbar godtas som likeverdige oversettelser av frail i medisinsk sammenheng. Det gir språklig variasjon samtidig som disse to begrepene til sammen nokså godt dekker dybden i det engelske frail.

Det motsatte av å være frail er å være fit. Også for dette uttrykket kan det være vanskelig å finne den beste oversettelsen. Sprek brukes mye, men gir etter mitt syn et inntrykk av at det bare handler om å være veltrent. Fitness som geriatrisk begrep favner bredere, og robust er etter min mening en vel så god oversettelse.
Torgeir Bruun Wyller

t.b.wyller@medisin.uio.no

Geriatrisk avdeling

Oslo universitetssykehus

Torgeir Bruun Wyller (f. 1960) er spesialist i indremedisin og i geriatri, professor ved Universitetet i Oslo og overlege.

\section{Litteratur}

1. Clegg A, Young J, Iliffe $S$ et al. Frailty in elderly people. Lancet 2013; 381: 752-62

2. Fried LP, Tangen CM, Walston $\mathrm{J}$ et al. Frailty in older adults: evidence for a phenotype. J Gerontol A Biol Sci Med Sci 2001: 56: M146-56.

3. Kristjansson SR, Rønning B, Hurria A et al. A comparison of two pre-operative frailty measures in older surgical cancer patients. J Geriatr Oncol 2012; 3: 1-7

4. Wyller TB. Geriatri - en medisinsk lærebok. Oslo: Gyldendal, 2011. 